and for shorter or later seasons. Other ${ }_{\infty}$ call for increased research on the species and for habitat improvement projects. Resolutions concerning season's are usually referred to the Game Advisory Committee and the others are usually carried unanimously by the delegates.

An interesting example is given of the hunting pressure that one Sarkatchewan sharptail population could stand and how the best estimate of the actual kill is well below this figure. Whether the data for this one area can be applied to the province as a whole calls for additional investigation. Other evidence that there is still much to be learned about this species can be seen in the assumptions that have to be made about migration and its effect on the populations in poor habitat and in heavily shot areas. The claim that predators kill "diseased and unfit sharptails" might also be worth investigating.

The management section might be criticized for not explaining the survey techniques on which regulations are based. It might offer some comfort to anxious naturalists and sportsmen to know what lengths the Wildlife Branch is going to ensure sound sharptail management. Present plans call for conservation officers in the Southern District to check dancing grounds in each game management zone (41 zones south of Prince Albert), aerial surveys are contemplated, the intensive researc program on the 16 square-mile stud: area west of Bulyea is being con tinued, kill surveys are being exten ded, and other phases of the sharp tail's ecology are being investigated

The entire series of conservatios bulletins is well worth reading - mor than once. - J. Bernard Gollor Canadian Wildlife Service, Saska toon.

\section{Wild Life of Australia and New Guinea}

By Charles Barrett

London, Wm. Heineman Ltd., 1955. 229 p., 36 pl., 83 illus. $21 \mathrm{~s}$.

Mr. Barrett describes the habit and habitats of kangaroos, cuscuse bandicoots, numbats, wombats, phas cogales, echnidnas, dingos, jerboa platypuses, whales, dugongs, emu cassowaries, brolgas, curlews, eagle hawks, trogmouths, cormorants, pet rels, pelicans, and fowls of swam] sea, water and jungle. There ax chapters on crocodiles, lizards an goannas, snakes, spiders and insect

I found especially interesting th. chapter on the megapodes (of whic the brush-turkey is a member which builds mounds to use as in cubators. Another intriguing speci, is the "tom-tit" which builds a two storey nest, the second storey prol ably being used by the male sleeping quarters - Tony Capuste Prince Albert.

\title{
Little Moments Make Big Days
}

A report of the S.N.H.S. Annual Meeting, October 18-19, 1957 by Elizabeth Cruickshank, Regina

We rose at dawn for the birding expedition that began the Saturday sessions of the Saskatchewan Natural History Society's annual meeting. At that early hour when we find all things made new, a dainty crescent moon glowed in the southern sky and Mercury supplied the candlelight. With the sun painting the eastern sky with shades of pink we drove to Regina college where Margaret Belcher and Helen Mann-both bright as the stars of the morningmet us with smiles, bubbling coffee, steaming pots of tea, and rolls.

Birders who get together twice a year excitedly exchanged experiences. Doctors, professors, and dentists, a nurse, an artist, a store-keeper ar a museum director, farmers, accour tants, teachers and housewive grandparents, middle-aged and you devotees-all young in heart as radiant. Sunrise is the time to enj birds, and people! George MacMill from Maple Creek disturbed no o: when he remarked "Birders are crazy, but it helps!"

Fred Bard led the motorcade to $t$ Waterfowl Park where his gee. answering his call, came sailing und the bridge. There are now ninet four birds; a month ago there we orie hundred. One bird shot with sight of home returned to the pa to die. 
There were ducks all over the water, a few crowding shoulder to shoulder in a sunny inlet. Sharing the sanctuary were three casualties - a pelican, a sandpiper and an avocet.

Many pairs of field glases were focussed on the birds. Fred Lahrman set up his tripod and 20 power glasses several times to settle arguments about the identification of certain species. Even experts, Bob Nero told us, dis a g re e among themselves! Twenty-eight species of water birds were checked and enjoyed and left behind at the sanctuary where we could continue to think of them protected from the hunter's gun.

From a thicket our first company of redpolls flew in chorus of soft twittering music. That made seventeen species other than water birds. Among the birds seen was a northern shrike. This led Steve Mann to tell us about the way in which he has observed these predators capturing sparrows. A shrike will perch not ar from a company of house sparrows. For some time no bird will nove. Then one sparrow will fly away. The shrike will pursue it. It will not return. We all wondered whether one bird was sacrificed to the shrike, and, if so, how that bird was chosen.

Another predator was busy in the marsh. A mink entered an opening in the bank; a muskrat came out as hough jet-propelled. The mink must have stayed in the den for breakfast, for we did not see him again.

Back at the Museum after the early pirding trip, members enjoyed a full lay's program of talks and pictures. John Hodges had observed birds in pocturnal flights, and wondered how hey fared in auroral storms. For Fred Lahrman it must have been a hrilling experience to be the bearer of the amazing pictures of the landpesting Western grebes and Bob Nero's story of them to the A.O.U. convention in New Jersey. Some of the scientific charts at the meeting may have looked, as he said, "like narled-up fishing gear," but there was nothing perplexing about the ine film and commentary he shared with us,

At the afternoon session, R. Folker explained the province's sharp-tailed brouse research program. We are glad hat we do not have to share his office piled high with wings and tails sent in by hunters to provide further data.

Short grass prairie is one environment without moss, but $M$. Welsh of Prince Albert gave such interesting information about moss and showed such beautiful slides that we were moved to feel that here was a hobby we should like to pursue, though collecting specimens would take us far from home.

Bernie Gollop discussed methods used to discourage ducks from feeding in grain fields. Since ducks can't read, it seems a hopeless task; even hunters, who can read and know better, trespass on farmers' fields!

Boyd Wettlaufer, as always, absorbed the attention of his audience as he described archaeological excavations at Estevan - the first major salvage program in Saskatchewan where man, causing destruction, is aware of it and prepared to salvage what he can. The archaeological story of Saskatchewan is just now beginning to be told, he said.

Members shared kodachromes representing their special interests: Tony Capusten showed us his oddest and most beautiful mushrooms; Elmer Fox featured his prize photo of an avocet; Dr. Houston showed his recent bird pictures; Dr. Rawson brought samples of mountain flowers and fish; and Mrs. Skinner shared with us a few pages from the life story of Squicker, a squirrel guest at their feeding station.

The evening address was given by W. Winston Mair, Chief of the Canadian Wildlife Service, who explained what that service means across Canada. A summary of his speech appears in this issue of the BLUE JAY.

On display in the rotunda of the Museum during the meeting was a fine collection of Rocky Mountain plants collected and pressed this summer by one of the youngest members of the society, nine-year-old Jonathon Gerrard of Saskatoon.

We look forward to next year's meetings in the north. We missed some of our regular members this year, but hope to meet them and others whom we know only by name at the summer meeting at Emma lake or at the 1958 annual meeting at Saskatoon. There is a kinship among all nature lovers which it is a delight to share. 